\title{
Level of Language Anxiety in Classroom among Students in a Higher Education Institute in Malaysia
}

\author{
Mohammad Ali Al-Saggaf ${ }^{1}$, Fatimatul Amirah Najla binti Mohd Zawawi ${ }^{1}$, Ali Hadi \\ Al-Aidaros 2 \\ ${ }^{1}$ School of Social Science, Management and Science University, Shah Alam 40100, Malaysia \\ ${ }^{2}$ Ministry of Education, Hadhramaut, Yemen
}

\begin{tabular}{llll}
\hline Received: 13.03.2021 & $\bullet$ & Accepted: 11.04.2021 & Published: 30. 06.2021
\end{tabular}

\begin{abstract}
The study aims to identify Higher Education students' level of language anxiety in the classroom. Moreover, the study also investigated the Higher Education Institute students' level of anxiety in each English language component. 236 students from a Higher Education Institute participated in this study. The quantitative method has been used in this study and a set of questionnaires was adapted from FLCAS developed by Horwitz et al. (1986). For the finding, the study found that Higher Education Institute students have a moderate level of language anxiety. Therefore, the study also revealed that the Higher Education Institute students have a moderate level of language anxiety in the test anxiety component and fear of negative evaluation component. On the other hand, Higher Education Institute students' have a high level of language anxiety in the communication apprehension component. The current study could help future educators to acknowledge more on language anxiety and help educators to find a good solution for these students
\end{abstract}

Keywords: Language anxiety; level of language anxiety; classroom

\section{Introduction}

According to Hilgard, Atkinson, Atkinson (1971) anxiety is a term of apprehension and the fear of the results of a coming or threatening situation or event. Anxiety also can be defined as a phenomenon which is controlled by the feeling of discomfort, nervousness, vague fear and apprehension that is not connected to a specific situation or event (Krashen, 1985, Atkinson, 1971). It has been supported by Horwitz, Horwit, and Cope (1986) which they viewed language anxiety as a combination of discrete mixture of attitudes, self-perceptions, habits, and learning-related emotions that resulted from the uniqueness of the language learning process. There are three components in language anxiety which are fear of negative evaluation, communication apprehension and test anxiety (Horwitz et al, 1986). These three components could also be contributing factors to language anxiety. The existence of language anxiety in ESL students will interrupt their performance in acquiring a second language (Chin, Ting and Yeo ,2016). The current research would like to determine the level of language anxiety among Higher Education Institute students and the level of each component in language anxiety which are communication apprehension, test anxiety and fear of negative evaluation 


\section{Literature Review}

\subsection{Level of Language anxiety}

Chin, Ting and Yeo (2016) examined English language anxiety among Uitm Sarawak undergraduate students. As English is an instruction medium in Universiti Teknologi MARA (UiTM) and the students are required to pass three levels of English proficiency courses in order to graduate, it somehow leads to the existence of anxiety. The finding revealed that majority of the respondents point out that they had experienced a moderate level language anxiety. While a very small group of the participants pointed out that they had experienced a high level of anxiety. There were four causal factors that contribute to this study. Under the factor of anxiety of English, students feel demotivated in attending English class. It can be seen that the highest value of mean was in the item of "I often feel like not going to my English class". Therefore, under the fear of tests, students were indicated that this is the major cause of anxiety. Majority of the students were related to the item "the more I prepare for English tests, the more confused I get". These students tend to get anxious when they have to construct a sentence with grammatically correct in such a short span of time. Moreover, the communication apprehension factor, the finding showed that the majority of the participants perceived themselves as being confident and not anxious in terms of communicating in English language. However, these students also reported they tend to get nervous when they are unable to comprehend the meaning of the certain words. Under the fear of negative evaluation factor, the finding reported that this factor gives least impact because of anxiety towards students which they were most worried about being left behind when the English classes move quickly.

Arif, Sapuan, and Isnin (2020) examine speaking anxiety in a communicative English classroom among Polytechnic students. The result showed that the majority of these students had a moderate level of speaking anxiety. Moreover, the result showed that these students also have moderate levels of anxiety in communication English classroom. Therefore, the factor that contributed to anxiety in communication English class was the fear of negative evaluation. It is because the students were getting nervous of the assumption and perceptions of the other students and the lecturers when they start to speak English. According to this finding, it has found that this behaviour is not healthy for students' performance in language learning. Due to that, the teachers were advised to apply the interesting method in language classroom, as well as creating a good environment in the class in order to motivate the student and enhance them into language classroom activity.

Al-Khasawaneh (2016) examine the problem that Saudi undergraduate EFL learners in language learning anxiety. The finding reported that the participants were in moderated anxiety in learning differences courses aside from English language course. The result in this present study are consistent with the previous studies (Rajanthran, Prakash, \& Husin, 2013; Gopang, Bughio, \& Pathan, 2015) who found moderate levels in the anxiety components as reported by the participants of their studies (Al-Khasawaneh, 2016). However, as revealed under sources of anxiety, communication apprehension showed the highest sources which the students have anxiety when they do not understand every word in English nor the words from the lecturers. These students tend to keep silent in class as they don't understand what other people are saying and they have been struggling to encounter the difficulties in understanding English language. As fear of negative evaluation, the participants feel anxious when the lecturers are about to give feedback, evaluating or correcting them. They also become more anxious if they were asked to do presentation without any 
preparation in advance. Additionally, under variance in language anxiety, senior student reported more anxious compared to sophomores, freshman and graduates. However, sophomores second highest score in overall language anxiety followed by freshman and graduates. These results prove that there was no positive reaction relationship between language anxiety and students' proficiency in English language (Batumlu \& Erden, 2007, Awan, Sabir \& Iqbal 2009) just like the previous studies. Moreover, this result was not as what the researchers expected which most of the previous studies showed that freshmen students are more anxious since their performance is less compared to sophomores and seniors. Other than that, these results showed that students might be anxious when they have to speak in front of their peers.

Alshahrani and Alshahrani (2015) explore the level of foreign language anxiety among EFL Saudi primary school students. The result showed that the students were at a moderate level of anxiety. In terms of language anxiety factors, the majority of the respondents accounted in communication apprehension. This follows with test anxiety and also fear of negative evaluation. Regarding the communication apprehension, more than half of participants answered that they feel anxious while speaking in the classroom during language learning. As for test anxiety, these students tend to feel anxious, tense and confused because of English class. On the other hand, to answer research question number three, the finding showed there was no general significance in the impact of gender on language anxiety.

Berowa (2018) studied Davao del Norte ESL learners' levels of language anxiety and studied the significant relationship between gender and students year-level. The purpose of the study was to provide insight on the levels of English language anxiety among ESL learners in Davao del Norte and it also explored the gender and year-level variables of the significant relationship between English anxiety and the success or failure in language learning. The findings showed that the level of language anxiety among respondents was at a neutral level. Moreover, the findings for the gender differences indicated slightly the same for both males and females. Although there are numerous investigations in the past indicating male students have always had a higher level of anxiety compared than female students, for this current study, the results showed males and females have shown the same level of anxiety.

Gopang, Bugrio and Pathan (2015) examined foreign language anxiety among English learning learners of students from the University of Pakistan. The objectives of the study is firstly, to investigate the level of foreign language anxiety among students at University level in Pakistan. Secondly, to explore different levels of second language anxiety between male and female students at University level. The findings revealed that the students feel fairy high anxiety in learning English. Moreover, from the findings, there was no significant difference in the level of anxiety among participants. Therefore, the study also showed that most of the students' level of anxiety higher that 3.01 score which means that these students indicated level of anxiety at moderate level. Hence, the gender differences should be by gender in this study. The small number of female participants was the limitations of the study. Therefore, the findings of the study may not be generalized to all populations.

Salim, et al., (2017) conducted a study on language anxiety among Kuala Lumpur Malaysia France Institute (UniKL MFI) in English language learning. The objective of the study is analyzing factors of language anxiety. As for findings, it showed that most of the students who participated in this 
study experienced the moderate level of foreign language anxiety. Therefore, the results also revealed that participants experienced a moderate level of foreign language anxiety in the three factors which are communication apprehension, test anxiety and fear of negative evaluation. However, students showed moderate and low levels of language anxiety in fear of negative feedback.

Alias and Rashid (2018) examined the relationship between students' language and learning anxiety among polytechnic students.. The finding revealed that the students in this study have moderate levels of language anxiety. There were also three types of anxiety tested: communication apprehension, language anxiety, and fear of negative evaluation. The results showed that there was a significant relationship between language anxiety and students' proficiency. In the case of that, the finding found out that the higher the students' proficiency in English language, the lower the test anxiety would be. In the other way, it has to be the higher students in test anxiety, the lower students in language proficiency.

\section{Methodology}

\subsection{Research Design}

The research used in this research is quantitative study. A set of questionnaires used as an instrument to obtain the data from the respondents. The questionnaire that has been used for this study was adapted from Foreign Language Classroom Anxiety Scale (FLCAS) that was developed by Horwitz et al. (1986). The questionnaire has been modified to be aligned with the current research's objectives and research questions.

\subsection{Sample}

The sampling for this study is students from School of Education and Social Science (SESS) in a Higher Education Institute in Malaysia among all the students who belong to the SESS faculty in MSU. There were only 236 who were involved in this study.

\subsection{Instrument}

The questionnaire that has been used for this study was adapted from Foreign Language Classroom Anxiety Scale (FLCAS) that was developed by Horwitz et al. (1986). Likert scale has been used in the questionnaire as it represents the respondents preference to answer the questions. In the questionnaire, number one represents 'Strongly disagree' whereas number 5 represents 'Strongly agree'.

\subsection{Pilot Study}

The researchers used Statistical Package for Social Sciences (SPSS) version 25 to see the reliability and validity of the instrument.. The instrument of the study got 0.854 for Cronbach's Alpha.

\subsection{Procedures and Data Analysis}

The questionnaire would be in Google Form and it has been distributed to the respondents which are Higher Education Institute in Malaysia students through online medium such application WhatsApp. There 
are many class groups in WhatsApp that have been a platform to distribute the questionnaire into a wider range. The data received for the questionnaire will be analyzed by using Statistical Package for Social Sciences (SPSS) version 25.

\section{Results And Discussion}

\subsection{Demographic Background}

\subsubsection{Gender.}

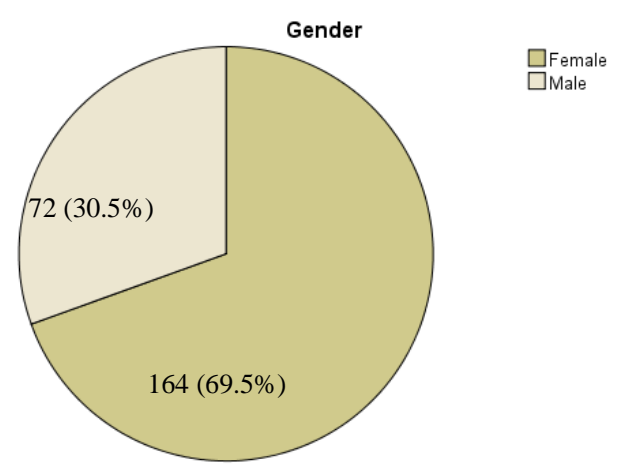

Figure 1. Percentage according gender

Figure 1 shows the percentage of the respondents according gender. Most of the respondents were from female students $69.5 \%(n=164)$ whereas respondents from male students $30.5 \%(n=75)$ were contributed in this study.

4.1.2 Age.

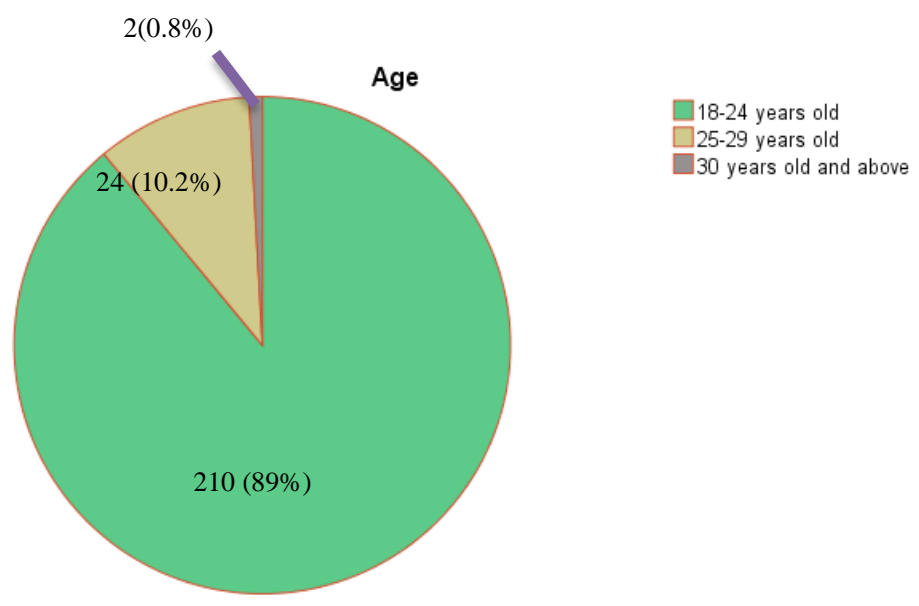

Figure 3. Percentage of ages

Figure 3 shows the ages of respondents. Most of the respondents were around 18 to 24 years old $89 \%$ $(\mathrm{n}=210)$. There were $10.2 \%(\mathrm{n}=24)$ of respondents from $25-29$ years old and only $0.8 \%(\mathrm{n}=2)$ of the respondents were 30 years old and above. 


\subsection{The Higher Education Institute in Malaysia Students' Level Of Language Anxiety}

Table 1. . Components of language anxiety

\begin{tabular}{|c|c|c|}
\hline No & Items & Mean \\
\hline $\mathbf{1}$ & Communication apprehension & $\mathbf{3 . 4 1}$ \\
\hline $\mathbf{2}$ & Test anxiety & $\mathbf{3 . 3 3}$ \\
\hline $\mathbf{3}$ & Fear of negative evaluation & $\mathbf{3 . 3 9}$ \\
\hline & AVERAGE MEAN & $\mathbf{3 . 3 7}$ \\
\hline
\end{tabular}

The table above shows the overall mean score of each factor in language anxiety. It can be seen that communication reached the highest mean score which is 3.41 whereas test anxiety mean reached the lowest score among three main factors which is 3.33. Meanwhile, fear of negative evaluation reached a 3.39 mean score. As for the total score for level of language anxiety among Higher Education Institute in Malaysia students, the average mean score is 3.37. It means that the respondents have moderate levels of language anxiety.

From the table above, it clearly shows that the respondents experience some level of anxiety in language learning. Thus, there are some variations, it can be seen that the mean of each level of anxiety and the overall mean results indicate that respondents have moderate levels of anxiety in language learning. The results of this current study appear to be consistent with the findings from the previous study which examined on English language anxiety among Uitm Sarawak undergraduate students (Chin et al., 2016). The finding revealed that the majority of the respondents point out that they had experienced a moderate level language anxiety. Other than that, there are another study investigated the level of language among university students which these studies found out the most of the university students recorded moderate level of language anxiety (Berowa, 2018; Latif, 2015; Arif et al., 2020; Al-Khasawaneh, 2016; Akkason, 2016; Alshahrani, 2015; Hamad, 2016; Phek et al., 2020; Seok et al., 2019; Alias et al., 2018; Gopang et al., 2015; Salim et al., 2017). From all of these studies, the respondents, which were university level learners revealed that they had experienced anxiety in learning language. However, the finding showed that the respondents have adequate levels of anxiety, which is not high but not low as well.

On the other hand, the table also shows that the highest factor of language anxiety among Higher Education Institute in Malaysia goes to communication apprehension as the mean score for this factor is 3.410. The score shows that the respondents from Higher Education Institute in Malaysia students have high levels of language anxiety in terms of communication apprehension (Berowa, 2018). This result happened to be similar with a previous study which the researcher examined on the problem of Saudi undergraduate EFL learners in language learning anxiety. The finding revealed that communication apprehension showed the highest score which the students have anxiety when they do not understand every word in English nor the words from the lecturers (Al-Khasawaneh, 2016). 
However, the current study shows a slight difference from the previous study where the finding of the study showed the highest score was on fear of negative evaluation (Arif et al., 2020). Hence, the study also indicated that the students have moderate levels of language anxiety.

Table 2. Mean Interpretation

\begin{tabular}{|l|l|}
\hline Interpretation & Mean \\
\hline Very high & $4.20-5.0$ \\
\hline High & $3.40-4.19$ \\
\hline Moderate & $2.60-3.39$ \\
\hline Low & $1.80-2.59$ \\
\hline Very low & $1.0-1.79$ \\
\hline
\end{tabular}

The table above shows that mean interpretation table. The mean interpretation table was taken from the previous study (Berowa, 2018). It can be a reference for the current study and future study to determine students' level of language anxiety.

\subsection{The Higher Education Institute in Malaysia Students' Level In Communication Apprehension Anxiety Of Students}

Table 3. Average mean of communication apprehension in language anxiety

\begin{tabular}{|c|c|}
\hline Items & Mean \\
\hline $\begin{array}{c}\text { I am sure of myself when I am speaking } \\
\text { in English in classroom }\end{array}$ & 3.7500 \\
classroom & 3.5000 \\
\hline $\begin{array}{c}\text { I feel confident when I speak English in } \\
\text { second language in front of the other } \\
\text { students }\end{array}$ & 3.2712 \\
\hline $\begin{array}{c}\text { I get nervous when I am speaking in class } \\
\text { speak English language than in my other } \\
\text { languages }\end{array}$ & 3.3263 \\
\hline $\begin{array}{c}\text { I feel more tense and nervous when I } \\
\text { speakers of the English language }\end{array}$ & 3.0763 \\
\hline AVERAGE MEAN & 3.5424 \\
\hline
\end{tabular}


The average mean table above shows that the mean for all of the items in communication apprehension are upper 3.0 mean score. It can be seen that the highest mean score among the items is the first item which has the mean score 3.7500. This results also indicates that item two and the last item are the second highest which both of these items have 3.5 and above mean score. The other items are still above 3.0, however, the mean score is still in moderate level. It is opposite to the items with 3.4 and above. Overall, the respondents have a high level of anxiety in terms of communication apprehension factor as the mean score is 3.410 .

As mentioned above, communication apprehension components appear the most highest among the three components in language anxiety. The table above shows the mean score of each item in the communication apprehension component. It can be seen that most of the items have a high mean score. However, some items have not reached a high level of language anxiety as the mean score for high level of language anxiety is at least 3.4. The result also brought the meaning behind this table which most of the respondents are easily get anxious if they happen not knowing the sentences of people being said. These students usually would keep quiet and isolated themselves from other people as they feel left out because they could not understand people' sentences. It was supported from the previous study (Chin, Ting and Yeo, 2016). The study examined on English language anxiety among UITM Sarawak undergraduate students and the results showed for the communication apprehension factor, the finding showed that the majority of the participants perceived themselves as being confident and not anxious in terms of communicating in English language. However, these students also reported they tend to get nervous when they are unable to comprehend the meaning of the certain words (Chin et al. 2016).

\subsection{The Higher Education Institute in Malaysia Students' Level In Test Anxiety}

Table 4. Average mean of test anxiety in language anxiety

\begin{tabular}{|c|c|}
\hline Items & Mean \\
\hline $\begin{array}{c}\text { Even if I am well prepared to speak } \\
\text { anglish language in classroom, I still feel } \\
\text { anxious about it }\end{array}$ & 3.5466 \\
\hline $\begin{array}{c}\text { I have no motivation to speak English in } \\
\text { my classroom because I can get anxious } \\
\text { easily }\end{array}$ & 2.8008 \\
\hline $\begin{array}{c}\text { I can feel my heart pounding when I'm } \\
\text { going to be called on in classroom }\end{array}$ & 3.5720 \\
\hline I feel pressure to prepare very well in \\
classroom
\end{tabular}

Table above shows the average mean of test anxiety in language anxiety. It can be seen that test anxiety is not as high as communication apprehension above. However, there are still items above 
3.4 mean score which indicates that the items reached a high level. There is only one item in test anxiety that reached a mean score below 3.4 which is 2.8 mean score. The overall mean for test anxiety is 3.3315 which is moderate level.

Table above also shows the average mean of the test anxiety in language anxiety. It can be seen that three out of four mean scores of each item in this component shows a high level of anxiety, however, it does not reflect the average mean on test anxiety component where it indicates students have moderate level of anxiety in test anxiety component with 3.3315 average mean score. Test anxiety in language anxiety is a fear or a worry of students to sit for their examinations. Most of the students with high level test anxiety agreed that they can easily forget all the things that they had studied due to anxiety to sit for exams. From the table above, it can be seen that these students are anxious to test anxiety. They also seemed to be under more pressure as they agreed with the items 'I feel pressure to prepare very well in the classroom'. The result was supported by the previous study where it showed that students feel demotivated in attending English class (Chin, Ting and Yeo, 2016). It was because the finding showed that the highest value of mean was in the item of "I often feel like not going to my English class". Therefore, under test anxiety, students were indicated that this is the major cause of anxiety. Majority of the students were related to the item "the more I prepare for English tests, the more confused I get". These students tend to get anxious when they have to construct a sentence grammatically correct in such a short span of time (Chin, Ting and Yeo, 2016).

\subsection{Higher Education Institute in Malaysia Students' Level In Fear Of Negative Evaluation Of Anxiety Of Students}

Table 5. Average mean of fear of negative evaluation

\begin{tabular}{|l|l|}
\hline \multicolumn{1}{|c|}{ Items } & \multicolumn{1}{|c|}{ Mean } \\
\hline $\begin{array}{l}\text { I am okay if I happen to make mistake while using English } \\
\text { language in classroom }\end{array}$ & 3.4958 \\
\hline $\begin{array}{l}\text { In classroom, I find myself thinking about others' perception } \\
\text { towards my proficiency in English language }\end{array}$ & 3.3941 \\
\hline $\begin{array}{l}\text { I keep thinking that the other students are better at languages } \\
\text { than I am }\end{array}$ & 3.5678 \\
\hline $\begin{array}{l}\text { I start to panic when I have to speak without preparation in } \\
\text { classroom }\end{array}$ & 3.5847 \\
\hline It embarrasses me to volunteer answers in any classroom & 2.9873 \\
\hline $\begin{array}{l}\text { I am afraid that my lecturer is ready to correct every mistake } \\
\text { I make }\end{array}$ & 3.0847 \\
\hline $\begin{array}{l}\text { I feel more anxious when the other students speak the English } \\
\text { language better than I do }\end{array}$ & 3.3814 \\
\hline $\begin{array}{l}\text { I get nervous when the lecturer asks questions that I haven't } \\
\text { prepared in advance }\end{array}$ & 3.6695 \\
\hline \multicolumn{1}{|c|}{ AVERAGE MEAN } & $\mathbf{3 . 3 9 5 6}$ \\
\hline
\end{tabular}


From the table above, it can be seen that most of the mean of each item in fear of negative evaluation are upper than 3.0 mean score. The highest mean is the last item out of eight items with the mean score 3.6695. Meanwhile the lowest mean score is the item number 5 which is 2.9873 . However, it would not be low level because the mean score is included in the moderate level. Whereas, the rest of the mean score indicates moderate level. As the average mean of fear of negative evaluation, it reached a moderate level of anxiety with a 3.3965 mean score.

Table 5 also shows the average mean of fear of negative evaluation. As it can be seen that out of three components in language anxiety, fear of negative evaluation component items are at most. However, it does not affect the level of its anxiety as fear of negative evaluation component is the most low average mean which is 3.3956. In this component, the average mean score shows that the respondents have moderate levels of anxiety in fear of negative evaluation. Fear of negative evaluation is a fear of a student to the feedback that they have received. These people usually are afraid of being graded by the teacher. However, some researchers believed that feedback could be a good component in language learning (Davoud et al. 2015). The researcher also believed that there are some students willingly to get the feedback from the teacher (Davoud et al., 2015). However, this findings are slightly different from the previous where the finding reported that this factor gives least impact because of anxiety towards students which they were most worried about being left behind when the English classes move quickly (Chin, Ting \& Yeo, 2016).

\section{Conclusion}

To sum up everything that has been stated so far, the result actively demonstrates that Higher Education Institute in Malaysia students experienced language anxiety although in moderate level of language anxiety. Moreover, the study found out that the respondents from Higher Education Institute in Malaysia students also have a high level of language anxiety in the communication apprehension component. Therefore, in component test anxiety and fear of negative evaluation, these students have language anxiety in moderate level of anxiety. Although this Higher Education Institute in Malaysia used English language as a communication medium in campus and also for learning purposes, these results showed that there are some students who are having anxiety in English language.

\section{References}

[1] Alias, A. B., \& Rashid, N. A. B. N. (2018). The relationship between students' second language learning anxiety and language proficiency. Journal of Counseling and Educational Technology, l(2), 50. https://doi.org/10.32698/0141

[2] Al-Khasawneh, F. (2016). Investigating foreign language learning anxiety: a case of Saudi undergraduate EFL learners. Journal of Language and Linguistic Studies, 12(1), 137-148. Retrieved from https://files.eric.ed.gov/fulltext/EJ1105172.pdf

[3] Chin, V., Yeo Jiin Yih, \& Hie-Ling Ting. (2016). Investigating English Language Anxiety among UiTM Sarawak Undergraduates. Retrieved June 29, 2021, from ResearchGate website: https://www.researchgate.net/publication/332217804_Investigating_English_Language_Anxiety _among_UiTM_Sarawak_Undergraduates

[4] Fauziah Binti Aarif, Ahmad FAIZ Sapuan, \& Siti Fazlina. (2020, September 14). Exploring Speaking Anxiety in Communicative English Classrooms at a Polytechnic in Malaysia. Retrieved June 29, 2021 , from 
https://www.researchgate.net/publication/344234728_Exploring_Speaking_Anxiety_in_Comm unicative_English_Classrooms_at_a_Polytechnic_in_Malaysia

[5] Illahi Bux Gopang, Faraz Ali Bughio, \& Habibullah Pathan. (2015, October). Investigating Foreign Language Learning Anxiety among Students Learning English in A Public Sector... Retrieved June 29, 2021, from ResearchGate website: https://www.researchgate.net/publication/283316871_Investigating_Foreign_Language_Learnin g_Anxiety_among_Students_Learning_English_in_A_Public_Sector_University_Pakistan

[6] Iman, W., Vijayaletchumy Subramaniam, \& Arbaayah Ali Termizi. (2017, March). Foreign Language Anxiety (FLA) in English Language Classroom. Retrieved June 29, 2021, from ResearchGate website: https://www.researchgate.net/publication/321363418_Foreign_Language_Anxiety_FLA_in_En glish_Language_Classroom

[7] Mae, A., \& Berowa, C. (n.d.). Levels Of Language Anxiety Toward English: A Sample From Davao Del Norte. Retrieved from website: https://www.tojned.net/journals/tojned/articles/v08i03/v08i0312.pdf

[8] Merzin Alshahrani, \& Awad Alandal. (2015). An Investigation of Anxiety Among Elementary School Students Towards Foreign Language Learning. Studies in Literature and Language, 11(1), 29-40. Retrieved from http://www.cscanada.net/index.php/sll/article/view/7180/7777 